\title{
Environmental carcinogen exposure and lifestyle factors affecting cancer risk in Qatar: findings from a qualitative review
}

\author{
R. Denholm, ${ }^{1}$ J. Schüz, ${ }^{1}$ K. Straif, ${ }^{2}$ F.M.H. Ali, ${ }^{3}$ F. Bonas, ${ }^{3}$ O. Gjebrea, ${ }^{3}$ C. Sifton ${ }^{3}$ and A.C. Olsson ${ }^{7}$
}

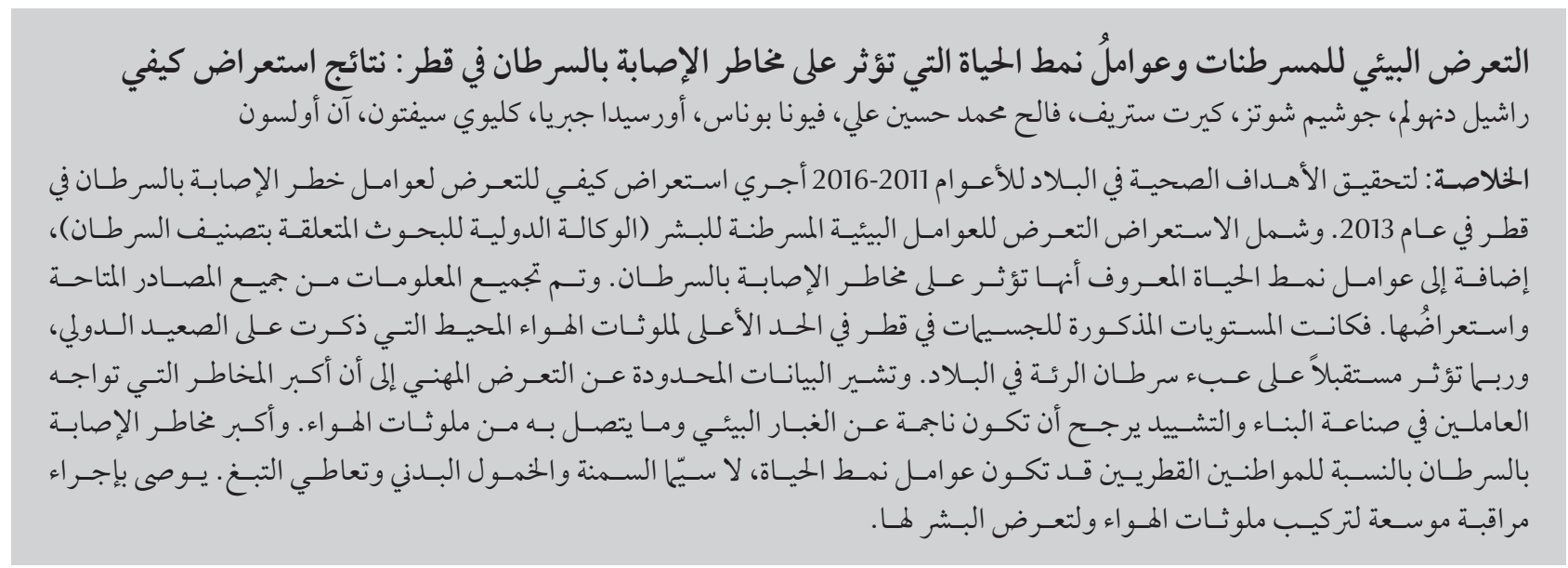

ABSTRACT To meet the country's health goals for 2011-2016, a qualitative review of exposure to risk factors for cancer in Qatar was conducted in 2013. The review included exposure to environmental agents carcinogenic to humans (International Agency for Research on Cancer classification), as well as lifestyle factors known to affect cancer risk. Information from all available sources was assembled and reviewed. The levels of particulate matter reported in Qatar were in the upper range of ambient air pollutants reported internationally, and may influence the country's future lung cancer burden. The limited data on occupational exposure suggests that the greatest risks for workers in the construction industry are likely to be from environmental dust and related air pollutants. The greatest cancer risks for Qatari nationals may be lifestyle factors, particularly obesity, physical inactivity and tobacco use. Extended monitoring of the composition of and human exposure to air pollutants is recommended.

Exposition aux carcinogènes environnementaux et facteurs associés aux modes de vie augmentant le risque de cancer au Qatar : résultats d'une analyse qualitative

RÉSUMÉ Afin d'atteindre les objectifs de santé fixés par le pays pour 2011-2016, une analyse qualitative de I'exposition aux facteurs de risque de cancer au Qatar a été conduite en 2013. L'analyse incluait l'exposition aux agents environnementaux cancérogènes pour l'homme (classification du Centre international de recherche sur le cancer) ainsi que les facteurs liés au mode de vie connus pour augmenter le risque de cancer. Des informations ont été rassemblées à partir de toutes les sources disponibles et ont fait l'objet d'un examen. Les niveaux de particules rapportés au Qatar se situaient dans la fourchette haute des polluants atmosphériques ambiants au niveau mondial, ce qui pourrait influencer la charge future du cancer du poumon dans le pays. Le nombre limité de données sur l'exposition professionnelle suggère que les risques les plus importants pour les professionnels de l'industrie du bâtiment seraient liés à la poussière environnementale et aux polluants atmosphériques qu'elle contient. Les risques de cancer les plus élevés pour les Qatariens proviendraient de facteurs associés aux modes de vie, en particulier l'obésité, la sédentarité et le tabagisme. Un suivi accru de la composition des polluants atmosphériques et de l'exposition de l'homme à ces derniers est recommandé.

'Environment and Radiation Section; ${ }^{2}$ IARC Monographs Section, International Agency for Research on Cancer, Lyon, France (Correspondence to A.C. Olsson: olssona@iarc.fr). ${ }^{3}$ Supreme Council of Health, Doha, Qatar.

Received: 02/09/15; accepted: 22/02/16 


\section{Introduction}

Globally, overall cancer incidence and mortality rates are increasing (1). Environmental factors that are potentially preventable make an important contribution to the burden of cancer worldwide (2). These include factors such as exposure to environmental air pollution, occupational exposure to carcinogenic compounds, and lifestyle factors such as dietary choices and exposure to tobacco smoke.

In Qatar, malignant neoplasms were the leading cause of death in women and the sixth most frequent cause of death in men in 2009 (3). A key recommendation of the Qatar national cancer strategy for the years 2011-16 was to carry out a review of environmental carcinogens in the country (4). The country's national health strategy for the same period had the explicit aim of developing national occupational health standards, policies and regulations and a monitoring system (5). To inform and develop these important goals, the Supreme Council of Health of Qatar together with the International Agency for Research on Cancer (IARC) conducted a qualitative review in 2013 of environmental risk factors for cancer in Qatar. The initial scope of the review covered exposure to chemicals and pollutants classified by IARC as carcinogenic to humans. It was later decided to include a review of lifestyle factors that are known to influence cancer risk. The findings were compared with similar data from other regions of the world. This paper presents the main findings and discusses the challenges of determining cancer risk attributable to environmental exposures in the Qatari population.

\section{Methods}

Table 1 details the types of data collected and the sources of data for the overall review. Data were collected in the following categories: food quality (e.g. carcinogens found in food samples and bottled water); air quality (e.g. carcinogens in outdoor air and engine exhausts); behavioural factors (e.g. exposure to tobacco smoke; levels of obesity and physical activity); occupational measures (e.g. exposures to asbestos and crystalline silica); and medical diagnostics (e.g. exposure to $\mathrm{X}$-rays and selected diseases). The definitions of carcinogens were based on the January 2013 list of agents classified carcinogenic to humans (group 1) in the IARC monographs programme (Table 2) (6). Selected lifestyle factors that affect cancer risk were based on the IARC Handbooks of Cancer Prevention, which provide evaluations of the cancer-preventive potential of agents and interventions; this series is intended to complement the IARC monographs programme (6) and the European Code against Cancer, 4 th edition $(7,8)$.

The information was assembled and reviewed from all available resources about the occurrence, monitoring and legislation of carcinogenic exposures in air, water and food sources and about lifestyle choices in Qatar. Collaborators and stakeholders from relevant

\begin{tabular}{|c|c|c|c|}
\hline Type of data & Source & Data & $\begin{array}{l}\text { Carcinogens (IARC group } 1 \\
\text { carcinogens)/lifestyle factors } \\
\text { influencing cancer risk }\end{array}$ \\
\hline Food quality & $\begin{array}{l}\text { Central Food Laboratories, } \\
\text { Supreme Council for Health }\end{array}$ & $\begin{array}{l}\text { Routine data collection (random } \\
\text { sampling of imported food } \\
\text { items and bottled water from all } \\
\text { ports of entry by the Qatar Port } \\
\text { Authority section) 1999-2000, } \\
\text { January to March } 2013\end{array}$ & $\begin{array}{l}\text { Aflatoxins; nitrate or nitrite; lead } \\
\text { compounds; cadmium and } \\
\text { cadmium compounds; arsenic } \\
\text { and inorganic compounds }\end{array}$ \\
\hline \multirow[t]{2}{*}{ Air quality } & $\begin{array}{l}\text { Air Quality Department, Qatar } \\
\text { Ministry of Environment; WHO. } \\
\text { ambient (outdoor) air pollution } \\
\text { database, } 2014 \text { Global Health } \\
\text { Observatory }\end{array}$ & $\begin{array}{l}\text { Routine data collection from } \\
\text { three permanent air monitoring } \\
\text { stations since } 2007 \text {; and one } \\
\text { mobile station since } 2008\end{array}$ & $\begin{array}{l}\text { Outdoor air pollution (sulfur } \\
\text { dioxide; nitrogen dioxide; } \\
\text { ozone; carbon monoxide); } \mathrm{PM}_{10} \\
\text { and } \mathrm{PM}_{2.5}\end{array}$ \\
\hline & $\begin{array}{l}\text { Traffic Department, Ministry of } \\
\text { Interior }\end{array}$ & $\begin{array}{l}\text { Routine data collection from } \\
2002 \text { and } 2012\end{array}$ & Diesel engine exhaust \\
\hline Behavioural factors & $\begin{array}{l}\text { Public Health Department, } \\
\text { Supreme Council for Health }\end{array}$ & $\begin{array}{l}\text { World Health Organization } \\
\text { STEPwise report 2012, global } \\
\text { adult tobacco survey } 2013\end{array}$ & $\begin{array}{l}\text { Tobacco smoke, and second- } \\
\text { hand tobacco smoke, weight } \\
\text { control, physical activity }\end{array}$ \\
\hline $\begin{array}{l}\text { Occupational } \\
\text { measures }\end{array}$ & $\begin{array}{l}\text { Ministry of Labour and Social } \\
\text { Affairs }\end{array}$ & $\begin{array}{l}\text { Labour force sample survey } \\
2007,2008,2009 \text { and } 2011\end{array}$ & $\begin{array}{l}\text { Selected exposures (asbestos, } \\
\text { crystalline silica) in the main } \\
\text { industries according to CAREX) }\end{array}$ \\
\hline Medical diagnostics & Hamad Medical Corporation & Annual report 2011 & $\begin{array}{l}\text { Hepatitis B; hepatitis C; parasitic } \\
\text { diseases; HIV/AIDS|; X-radiation }\end{array}$ \\
\hline
\end{tabular}

$I A R C=$ International Agency for Research on Cancer; $C A R E X=$ European carcinogen exposure database; $P M_{10}=$ particulate matter 10 um or less in diameter; $P M_{25}=$ particulate matter $2.5 \mu \mathrm{m}$ or less in diameter. 


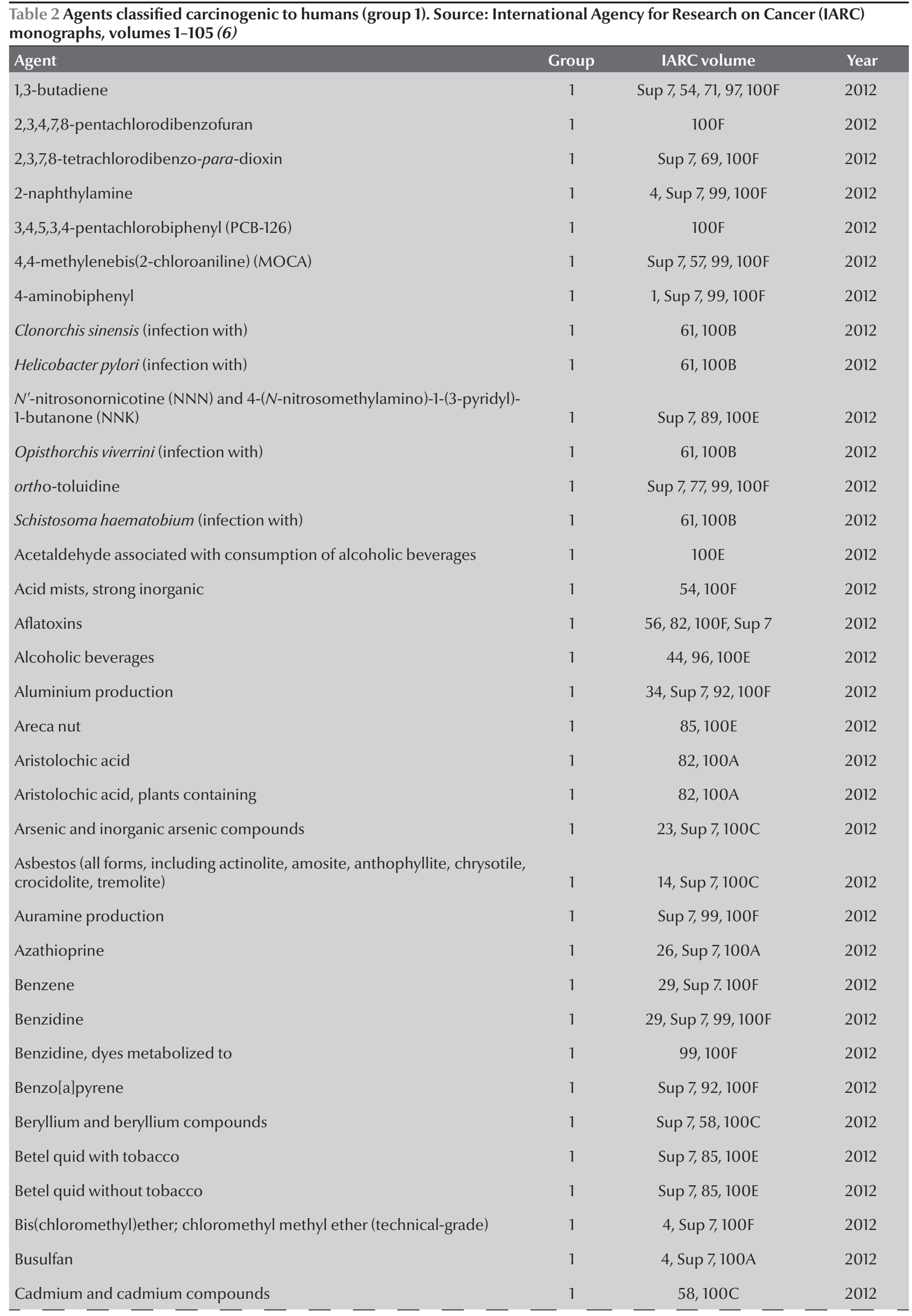




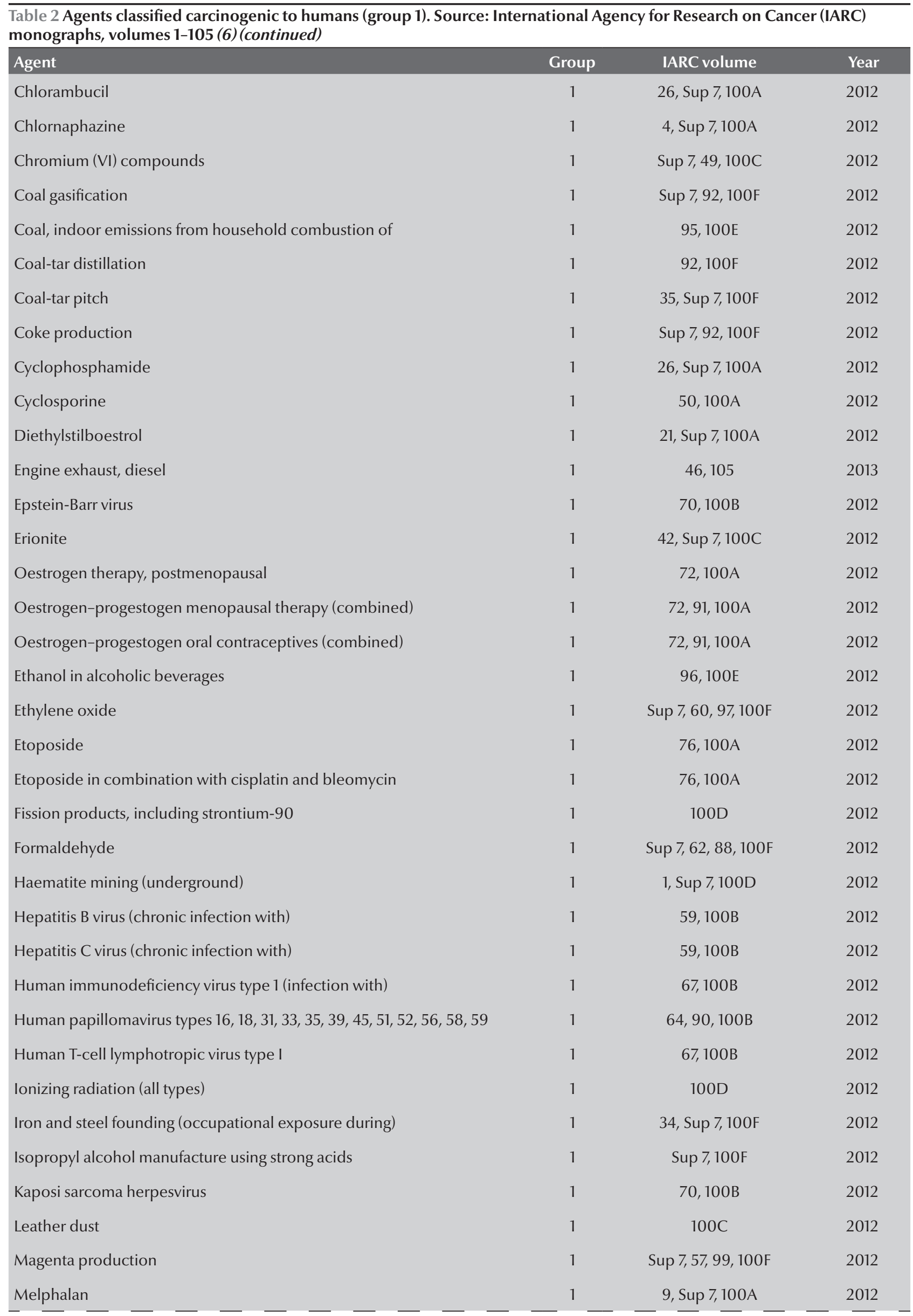




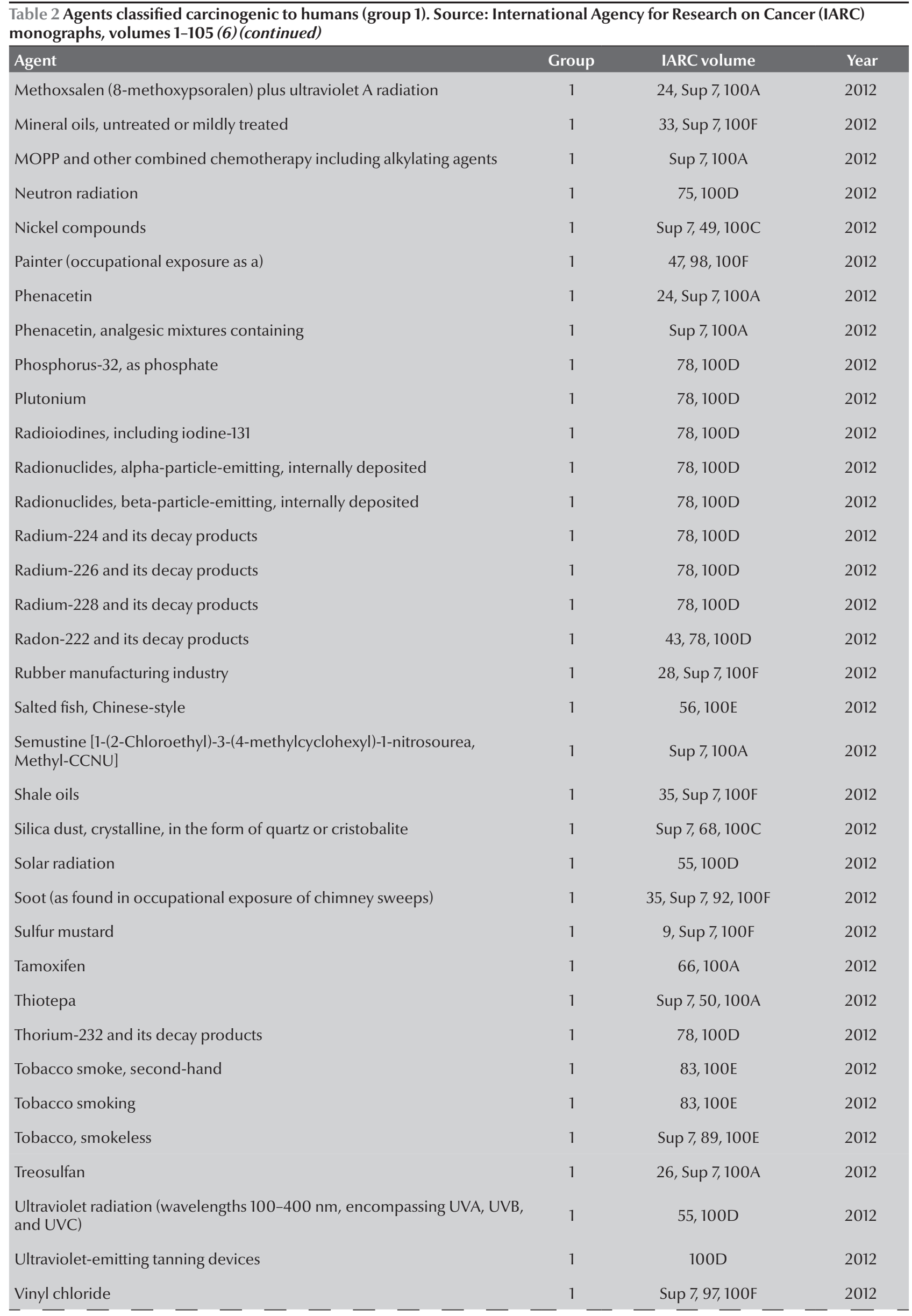




\begin{tabular}{lccc}
\hline $\begin{array}{l}\text { Table } 2 \text { Agents classified carcinogenic to humans (group 1). Source: International Agency for Research on Cancer (IARC) } \\
\text { monographs, volumes 1-105 (6) (concluded) }\end{array}$ & Group & IARC volume & Year \\
\hline Agent & 1 & $62,100 C$ & 2012 \\
Wood dust & 1 & $75,100 D$ & 2012 \\
X-radiation and gamma-radiation &
\end{tabular}

MOPP = mechlorethamine, oncovin, procarbazine, and prednisone .

government institutions and organizations were contacted for face-to-face meetings, and data from routine surveillance and other unpublished information were collected when possible. Data about air, water and food sources were obtained from the Government of Qatar's Central Food Laboratories, Air Quality Department and Traffic Department. An indication of X-ray exposure and disease prevalences were obtained from Hamad Medical Corporation, a non-profit national health organization. Data on the prevalence of tobacco smoking, obesity and physical inactivity were obtained from the World Health Organization's STEPwise report 2012 (9) and the Global Adult Tobacco Survey 2013 (10). No specific data on occupational exposures were available to us, although we used the Labour Force Statistics Bulletin of the Qatar Ministry of Development Planning and Statistics and attributed exposures to the main industries based on the European CAREX [carcinogen exposure] database $(11,12)$. We also discuss the likelihood of the most important exposures based on a review of published reports, including information from Qatar.

For comparison with other countries and regions we collected data from comparable sources, including the World Health Organization (WHO) STEPwise approach to Surveillance national reports (13) and WHO air pollution reports (14).

\section{Results}

\section{Air pollution}

Reported levels of air pollution in Qatar are higher than those for other countries in the Eastern Mediterranean Region (EMR) and some industrialized countries elsewhere in the world. In 2012, the annual mean levels of particulate matter $10 \mu \mathrm{m}$ or less in diameter $\left(\mathrm{PM}_{10}\right)$ in the capital city, Doha, were $168 \mu \mathrm{g} /$ $\mathrm{m}^{3}$, and for particulate matter $2.5 \mu \mathrm{m}$ or less in diameter $\left(\mathrm{PM}_{2.5}\right)$ were 93 $\mu \mathrm{g} / \mathrm{m}^{3}$ (14). Levels reported in Doha exceeded those from other large cities in the region such as Abu Dhabi and internationally including Beijing (Figure 1).

Few studies have investigated air pollution composition in the region. The United States of America (USA) enhanced particulate matter surveillance programme conducted chemical and physical analysis of air pollution in USA army bases across the Middle East, including Al Udied, south-west of Doha $(15,16)$. The programme showed a $\mathrm{PM}_{10}: \mathrm{PM}_{25}$ mass ratio of 0.41 , indicating a high fraction of $\mathrm{PM}_{10}$ was composed of coarse dust in the air. High concentrations of sulphate in $\mathrm{PM}_{2.5}$ were also found, most likely from sulfur

Annual mean PM2.5 $\mu \mathrm{g} / \mathrm{m}^{3}$

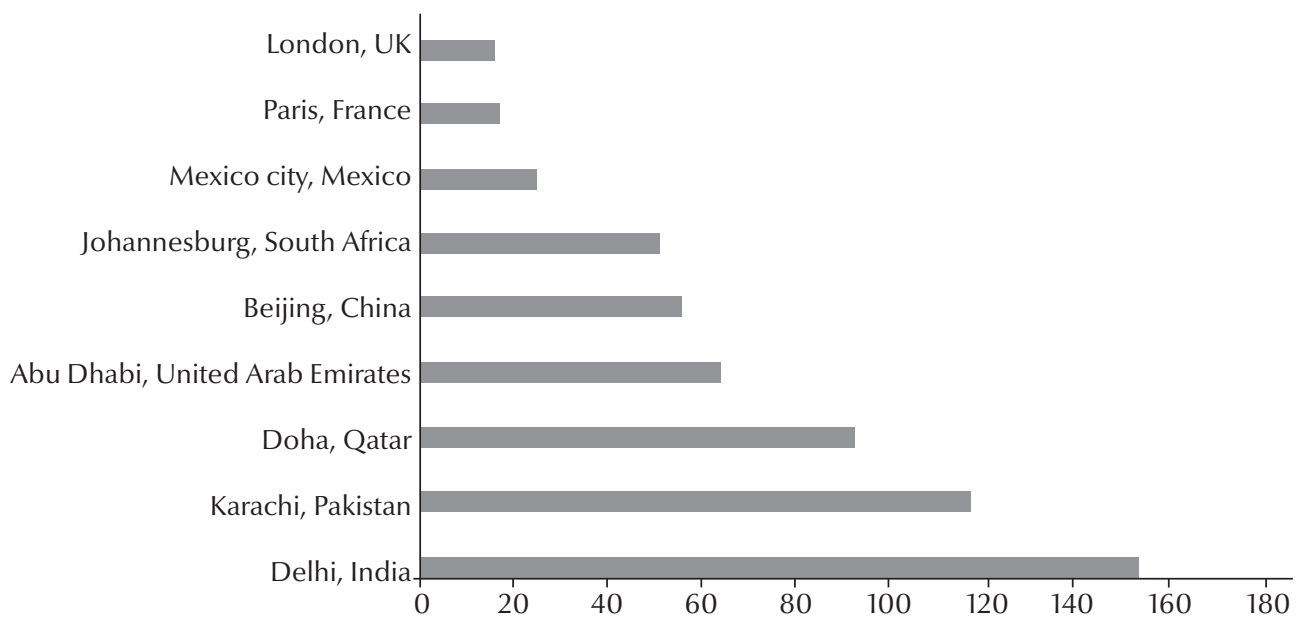

Figure 1 Levels of particulate matter $2.5 \mu \mathrm{m}$ or less in diameter $\left(\mathrm{PM}_{2.5}\right)$ in selected cities for the last available year over the period 2008-2013. Source: World Health Organization ambient (outdoor) air pollution in cities database 2014 (14) 
dioxide emissions from petrochemi$\mathrm{cal}$ and other industries. Overall, the report concluded that there was little difference in the dust composition in Middle Eastern countries compared with Djibouti, China and the USA.

\section{Occupational exposures}

Building construction is currently the dominant industry in Qatar, employing more than 568000 workers in 2013 (17). The majority (99.7\%) of construction workers are non-Qatari nationals, while most Qatari nationals are employed in the public administration and defence sector (53.7\%) (17). The main type of aggregates used for concrete constructions have changed from local limestone to imported gabbro, a mafic igneous rock, containing less silica and more iron and magnesium compared with quartz $(18,19)$. The USA geological survey show that countries of the Middle East have consumed relatively low levels of asbestos compared with other countries, and only small quantities have been imported to Qatar: 1390 metric tons in 2005, decreasing to 23 metric tons in 2007 (20). Qatar has banned the import of chrysotile asbestos $(21)$.

Oil and gas activities represent the main source of revenue for the Government of Qatar and include exploration, production and refining. Technologies used for the extraction of natural gas are to a large extent automated and therefore do not need a large workforce (17). In addition, most processes are in closed systems, with little potential for exposure of humans to hazardous agents.

\section{Lifestyle factors}

A 2012 survey of Qatari nationals found that $70.1 \%$ of participants were classified as either overweight [body mass index (BMI) $\left.25-29 \mathrm{~kg} / \mathrm{m}^{2}\right]$ or obese (BMI $\left.\geq 30 \mathrm{~kg} / \mathrm{m}^{2}\right)$ and nearly half (45.0\%) reported a low level of physical activity. Obesity levels were comparable in both sexes, with $40.0 \%$ of men and $43.0 \%$ of women aged 18-64 years having a
BMI $\geq 30 \mathrm{~kg} / \mathrm{m}^{2}$, while more women compared with men were physically inactive ( $54.2 \%$ and $37.4 \%$ respectively) (9). The overall prevalence of tobacco smoking in 2013 was $20.2 \%$ in men and $3.1 \%$ in women aged $15+$ years, with the proportion increasing to about $25 \%$ in Qatari men aged $25+$ years. Waterpipe tobacco was smoked by $3.4 \%$ of the population, a higher proportion of men compared with women $(4.9 \%$ and $1.6 \%$ respectively) (10).

\section{Discussion}

The original aim of this project was to provide a qualitative and quantitative review of the burden of cancer in Qatar attributable to different environmental and occupational carcinogens. The review was limited, however, to a qualitative assessment of cancer risk because quantitative data on exposures were scarce or unavailable. For example, international companies working in Qatar apply their own international standards for surveillance of occupational exposures. Information from individual companies was not made available to us and therefore we were unable to estimate the number of workers exposed to different occupational carcinogens.

The levels of air pollution reported in Qatar exceed those reported by European and North American countries, and thus may influence the country's future lung cancer burden (22). $\mathrm{PM}_{10}$ and $\mathrm{PM}_{2.5}$ measurements from Qatar substantially (23) $\left(\mathrm{PM}_{2.5}\right.$ annual mean $=10 \mu \mathrm{g} / \mathrm{m}^{3}$ ) and were in the upper range of ambient air pollutants reported internationally. Particulate matter from outdoor air pollution is classified as carcinogenic to humans by the IARC monographs programme (22). However, the evidence for the association between $\mathrm{PM}_{10}$ and cancer risk is based largely on epidemiological studies from Europe and North America $(24,25)$. There are no large-scale studies that have investigated cancer risk associated with exposure to particulate matter in arid settings, where a large proportion of the atmospheric particulate matter is expected to be sand particles from the land. Evidence from the enhanced particulate matter surveillance programme indicate that the composition of particulate matter in the Middle East is comparable to that of other arid regions $(15,16)$. However, human exposure to environmental air pollution is influenced by meteorological factors and individual behaviour, such as the time spent outdoors and individual levels of activity, which are likely to be different in Qatar compared with countries of Europe and North America due to the hot climate and social customs. Extended monitoring, including assessing concentrations of air pollutants and, in particular, personal exposure monitoring, is needed to better understand the extent to which lung cancer risk estimates from Europe and North America are valid for the population of Qatar.

Little is known about occupational exposure to carcinogens in Qatar. The exposure to occupational carcinogens in different industries have been assessed in studies from other countries, for example the European CAREX [carcinogen exposure] database $(11,12)$. The relevance of such databases are likely to be limited to Qatar and other EMR countries, due to the use of different materials, processes and technologies. For example, in Europe and North America the sand used for concrete is rich in quartz, which contains crystalline silica, a group 1 carcinogen. The frequent exposure to crystalline silica has contributed to the construction industry being classified as a high-risk activity. In Qatar, the predominant materials used in construction are limestone and gabbro, which have lower levels of silica compared with quartz. Thus, the risk of exposure to silica in the construction industry in Qatar is likely to be lower compared with Europe and North America, with a correspondingly lower lung cancer risk. Qatari nationals 
are mostly employed in office-based activities with low potential for exposure to known occupational carcinogens (17), while for the mostly expatriate workers in the construction industry, our review suggests that greatest problems related to carcinogen exposure are likely to be environmental dust and related air pollutants.

A weakness of our review was lack of access to information on occupational exposures, including what agents were used and at what levels. A further challenge in assessing the cancer risk is that many workers in the potentially highrisk occupations are non-Qatari nationals who tend to stay in the country for a relatively short time (26). Cancer most often occurs several years after the exposure; the follow-up required to assess cancer risk associated with occupational exposures may therefore be challenging in this dynamic population.

Data compiled by the Institute for Health Metrics and Evaluation at the University of Washington shows that Qatar has the sixth highest prevalence of overweight and obesity (body-mass index of over $25 \mathrm{~kg} / \mathrm{m}^{2}$ ) among people aged 20 years and older in the world, after Tonga, Samoa, Kiribati, Kuwait and the Marshall Islands (27). Having a healthy body weight protects against cancers of the oesophagus (adenocarcinoma), colorectum, gall bladder, pancreas, breast (postmenopausal), endometrium, ovary, kidney (renal cell) and prostate cancer (advanced), while regular physical activity protects against cancers of the colon, breast and endometrium $(7,8)$. A healthy body weight and regular physical activity is, after tobacco control, the second most important way to prevent cancer (28). Given the relatively high proportion of overweight and obesity and that almost half of the population report low physical activity suggests that, for Qatari nationals, lifestyle factors, in particular obesity, physical inactivity and tobacco use, could pose the greatest risk of cancer. Preventive action here is likely to have the greatest influence on future cancer trends in Qatar. Tobacco use increases the risk of many different cancers and therefore represents a large component of the cancer risk in Qatar, although the prevalence of tobacco use is comparatively low compared with other countries worldwide (29).

The current cancer burden in Qatar is relatively small compared with Europe and North America (30). However, as life expectancy in Qatar increases it is expected that the incidence of cancer will increase in the future (31). Lifestyle factors are likely to play the greatest role in cancer trends. National strategies have been developed to target obesity and physical inactivity in the population and Qatar is part of the WHO Framework Convention on Tobacco Control. Continued surveillance of different age groups and evaluation of preventive measures are warranted. Relatively high levels of ambient air pollution have been reported in Qatar, and are expected to contribute to the population's future lung cancer burden. There were few data on occupational exposures available to us, and therefore the influence of carcinogens in industrial settings on the cancer burden remains unknown. Future research is needed to obtain more extensive data on the composition of environmental air pollutants and in particular personal monitoring, as well occupational exposures associated with new industries in the country, to fully understand their potential influence on the cancer burden in the population.

Funding: None.

Competing interests: None declared.

\section{References}

1. Ferlay J, Soerjomataram I, Ervik M, Dikshit R, Eser S, Mathers C, et al. GLOBOCAN 2012 v1.0. Cancer incidence and mortality worldwide: IARC CancerBase No. 11. Lyon, France: International Agency for Research on Cancer; 2013.

2. Cancer prevention \{Internet]. Geneva: World Health Organization; 2015 (Available from: http://www.who.int/cancer/ prevention/en/, accessed 26 April 2016).

3. Deaths by cause of death, age and sex (WHO data). New York: United Nations Statistics Division; 2016 (Available from: http://data un org/Data aspx?d=POP\&f=tableCode\%3A105, accessed 26 April 2016).

4. National cancer strategy: the path to excellence, 2011-2016. Doha: Supreme Council of Health; 2012 (Available from: http://nhsq info/app/media/878, accessed 26 April 2016).

5. National health strategy 2011-2016. Project implementation plans update 2013. Doha: Supreme Council of Health; 2013 (Available from: http://nhsq info/app/media/1029, accessed 26 April 2016).

6. IARC monographs on the evaluation of carcinogenic risks to humans. List of classifications, volumes 1-115 [Internet]. Lyon: International Agency for Research on Cancer (Available from: http://monographs.iarc.fr/ENG/Classification/latest_classif. php https://monographs.iarc.fr/ENG/Classification/ClassificationsAlphaOrder.pdf, accessed 26 April 2016).

7. Anderson AS, Key TJ, Norat T, Scoccianti C, Cecchini M, Berrino $F$, et al. European code against cancer 4th edition: obesity, body fatness and cancer. Cancer Epidemiol. 2015 Dec;39 Suppl 1:S34-45. PMID:26205840

8. Leitzmann M, Powers H, Anderson AS, Scoccianti C, Berrino F, Boutron-Ruault MC, et al. European code against cancer 4th edition: physical activity and cancer. Cancer Epidemiol. 2015 Dec;39 Suppl 1:S46-55. Epub 2015 Jul 15.

9. Haj Bakri A, Al-Thani A. Qatar STEPS report 2012. Chronic disease risk factor surveillance. Doha: Supreme Council of Health; 2013 (Available from: http://www.who.int/chp/ steps/Qatar_2012_STEPwise_Report.pdf?ua=1, accessed 26 April 2016).

10. The global adult tobacco survey fact sheet. Cairo: WHO Regional Office for the Eastern Mediterranean; 2013 (Available from: http://www.emro.who.int/images/stories/tfi/ documents/FACT_SHEETS/FS_GATS_Qatar_2013.pdf?ua=1, accessed 26 April 2016).

11. Driscoll T, Nelson DI, Steenland K, Leigh J, Concha-Barrientos $M$, Fingerhut $M$, et al. The global burden of disease due to 
occupational carcinogens. Am J Ind Med. 2005 Dec;48(6):419 31. PMID:16299703

12. Kauppinen T, Toikkanen J, Pedersen D, Young R, Ahrens W, Boffetta $P$, et al. Occupational exposure to carcinogens in the European Union. Occup Environ Med. 2000 Jan;57(1):10-8. PMID:10711264

13. Prevalence of noncommunicable disease risk factors in some countries in Eastern Mediterranean. STEPwise survey. Geneva: World Health Organization; 2013 (Available from: http:// www.emro.who.int/noncommunicable-diseases/information-resources/ncd-risk-factors-prevalence.html, accessed 26 April 2016).

14. Ambient (outdoor) air pollution in cities database 2014. Geneva: World Health Organization; 2015 (Available from: http:// www.who.int/phe/health_topics/outdoorair/databases/cities/en/, accessed 26 April 2016).

15. Engelbrecht JP, McDonald EV, Gillies JA, Jayanty RK, Casuccio G, Gertler AW. Characterizing mineral dusts and other aerosols from the Middle East-part 2: grab samples and re-suspensions. Inhal Toxicol. 2009 Feb;21(4):327-36. PMID:19235611

16. Engelbrecht JP, McDonald EV, Gillies JA, Jayanty RK, Casuccio G, Gertler AW. Characterizing mineral dusts and other aerosols from the Middle East-part 1: ambient sampling. Inhal Toxicol. 2009 Feb;21(4):297-326. PMID:19235610

17. Bulletin labor force statistics 2012. Doha: Ministry of Development Planning and Statistics; 2013 (Available from: http://www.qix.gov.qa/portal/page/portal/QIXPOC/Documents/QIX\%20Knowledge\%20Base/Publication/Labor\%20 Force\%20Researches/labor\%20force\%20sample\%20survey/ Source_QSA/Labour_Force_Statistics_QSA_Bu_AE_2012.pdf, accessed 26 April 2016).

18. Al-Ansary M, lyengar S. Physiochemical characterization of coarse aggregates in Qatar for construction industry. International Journal of Sustainable Built Environment. 2013;2(1):27-40.

19. Press F, Siever R, Grotzinger J, Jordan T. Understanding earth. 4th ed. New York: W.H. Freeman; 2003.

20. Virta RL. World asbestos consumption from 2003 through 2007. Reston (VA): United States Geological Survey; 2009 (Available from: (http://minerals.usgs.gov/minerals/pubs/ commodity/asbestos/mis-2007-asbes.pdf, accessed 26 April 2016).

21. Chrysotile asbestos. Geneva: World Health Organization; 2014 (Available from: http://www.who.int/ipcs/assessment/ public_health/chrysotile_asbestos_summary.pdf, accessed 26 April 2016).

22. IARC working group on the evaluation of carcinogenic risks to humans. A review of human carcinogens. IARC Monographs on the Evaluations of Carcinogenic Risks to Humans. Volume 109. Ambient air pollution. Lyon: International Agency for Research on Cancer; 2013.

23. Air quality guidelines global update 2005. Copenhagen: WHO Regional Office for Europe; 2006.

24. Raaschou-Nielsen O, Andersen ZJ, Beelen R, Samoli E, Stafoggia $M$, Weinmayr $G$, et al. Air pollution and lung cancer incidence in 17 European cohorts: prospective analyses from the European Study of Cohorts for Air Pollution Effects (ESCAPE). Lancet Oncol. 2013 Aug;14(9):813-22. 10.1016/S14702045(13)70279-1 PMID:23849838

25. Lepeule J, Laden F, Dockery D, Schwartz J. Chronic exposure to fine particles and mortality: an extended follow-up of the Harvard Six Cities study from 1974 to 2009. Environ Health Perspect. 2012 Jul;120(7):965-70. PMID:22456598

26. 26. Gardner A, Pessoa S, Diop A, Al-Ghanim K, Le Trung K, Harkness L. A portrait of low-income migrants in contemporary Qatar. Journal of Arabian Studies. 2013;3(1):1-17.

27. Ng M, Fleming T, Robinson M, Thomson B, Graetz N, Margono $\mathrm{C}$, et al. Global, regional, and national prevalence of overweight and obesity in children and adults during 1980-2013: a systematic analysis for the Global Burden of Disease Study 2013. Lancet. 2014 Aug 30;384(9945):766-81. PMID:24880830

28. IARC working group on the evaluation of carcinogenic risks to humans. Preventive strategies. Volume 6. Weight control and physical activity. Lyon: International Agency for Research on Cancer; 2001.

29. Asma S, Mackay J, Song S, Zhao L, Morton J, Palipundi K. The GATS atlas. Global adult tobacco survey. Atlanta (GA): CDC Foundation; 2015.

30. Cancer incidence in five continents. Volume X [Internet]. Lyon: International Agency for Research on Cancer [IARC Scientific Publication No. 164] (Available from: http://www. iarc.fr/en/publications/pdfs-online/epi/sp164/, accessed 26 April 2016).

31. Salomon JA, Wang H, Freeman MK, Vos T, Flaxman AD, Lopez AD, et al. Healthy life expectancy for 187 countries, 1990-2010: a systematic analysis for the Global Burden Disease Study 2010. Lancet. 2012 Dec 15;380(9859):2144-62. PMID:23245606 